\title{
PENGESAMPINGAN PERKARA DEMI KEPENTINGAN UMUM PASCAPUTUSAN MAHKAMAH KONSTITUSI
}

\author{
Ani Triwati, \\ ani.triwati@usm.ac.id \\ Fakultas Hukum Universitas Semarang, Semarang
}

\begin{abstract}
Abstrak
Penelitian ini bertujuan untuk menganalisis pengesampingan perkara demi kepentingan umum pascaputusan Mahkamah Konstitusi Nomor 29/PUUXIV/2016. Mengesampingkan perkara demi kepentingan umum sebagai pelaksanaan asas oportunitas diatur dalam Undang-Undang Nomor 16 Tahun 2004 tentang Kejaksaan Republik Indonesia Pasal 35 huruf c, merupakan kewenangan jaksa agung. Pengujian Pasal 35 huruf c Undang-Undang Nomor 16 Tahun 2004 tentang Kejaksaan Republik Indonesia terhadap Undang-Undang Dasar telah diputus Mahkamah Konstitusi dalam Putusan Nomor 29/PUU-XIV/2016. Permasalahan difokuskan pada bagaimana pengenyampingan perkara demi kepentingan umum sebagai pelaksanaan asas oportunitas dalam penuntutan dan bagaimana pengesampingan perkara demi kepentingan umum pascaputusan Mahkamah Konstitusi Nomor 29/PUU-XIV/2016. Jenis penelitian yang digunakan adalah yuridis normatif, dengan spesifikasi penelitian dilakukan secara deskriptif analitis. Pengesampingan perkara demi kepentingan umum sebagai pelaksanaan asas oportunitas dalam penuntutan, memberikan pilihan pada jaksa penuntut umum untuk menuntut perkara tersebut atau mengesampingkannya sehingga tidak dilakukan penuntutan. Mengesampingkan perkara demi kepentingan umum berdasarkan Pasal 35 huruf c Undang-Undang Nomor 16 Tahun 2004 tentang Kejaksaan Republik Indonesia berikut Penjelasannya hanya dapat dilakukan oleh jaksa agung setelah memperhatikan saran dan pendapat dari badan-badan kekuasaan negara yang mempunyai hubungan dengan masalah tersebut. Pengesampingan perkara demi kepentingan umum pascaputusan Mahkamah Konstitusi Nomor 29/PUU-XIV/2016, dapat dilakukan jaksa agung setelah kewajiban memperhatikan saran dan pendapat dari badan-badan kekuasaan negara yang mempunyai hubungan dengan masalah tersebut (perkara yang ditangani) dilaksanakan.
\end{abstract}

Kata kunci: Kepentingan Umum; Pascaputusan; Pengesampingan Perkara 


\title{
TURNING ASIDE CASES FOR PUBLIC INTEREST AFTER THE DECISION-MAKING OF CONSTITUTIONAL COURT
}

\begin{abstract}
The aim of this research are to find out and analyze leaving aside cases after the decision-making of the Constitutional Court Number 29 / PUU-XIV / 2016 Turning aside cases for public interest as the implementation of the principle of opportunity, is regulated in Law Number 16 of 2004 concerning the Attorney General's Office of the Republic of Indonesia Article 35 letter c, is the authority of the attorney general. Testing Article 35 letter c of Law Number 16 of 2004 concerning the Attorney General's Office of the Republic of Indonesia against the Republic of Indonesia has been decided by the constitutional Court in its decision Number 29 / PUU-XIV / 2016. The problem in this study is focused on how the leaving aside of cases for public interest as the implementation of the principle of opportunity in prosecution and how the leaving aside of cases in the public interest after the decision of the Constitutional Court Number 29 / PUU-XIV / 2016. This type of research is normative juridical, with research specifications conducted descriptively analytically. Leaving aside of cases for public interest as the implementation of the principle of opportunity in prosecution, gives the prosecutor the choice to prosecute the case whether set it aside with the result that prosecution is not carried out. Leaving aside cases for public interest based on Article 35 letter c of Law Number 16 of 2004 concerning the Attorney General's Office of the Republic of Indonesia and the explanation thereof, could only be done by the attorney general with the regard the suggestions and opinions from the state power agencies that have the correlation with the matter. Leaving aside of cases for public interest after the decision-making of the Constitutional Court Number 29 / PUU-XIV / 2016 could be carried out by the attorney general after implementing the obligation to observe the advice and opinions of the state power agencies that are related to the problem (case being handled).
\end{abstract}

Keywords: Public Interest; Leave Aside Case; After Decision-Making 


\section{PENDAHULUAN}

\section{A. Latar Belakang}

Hukum sebagai perwujudan sistem nilai-nilai mengandung arti, bahwa kehadirannya adalah untuk melindungi dan memajukan nilai-nilai yang dijunjung tinggi oleh masyarakatnya. ${ }^{1}$ Nilai-nilai tersebut akan dijabarkan dalam kehidupan yang bersifat praksis atau kehidupan yang nyata dalam masyarakat, bangsa maupun negara maka nilai-nilai tersebut kemudian dijabarkan dalam suatu norma-norma yang jelas sehingga merupakan suatu pedoman $^{2}$, di antaranya norma hukum. Norma hukum diwujudkan dalam bentuk aturan yang memuat rumusan perbuatan tertentu dan penegakannya dilakukan oleh alat-alat negara.

Sistem peradilan pada hakikatnya identik dengan sistem penegakan hukum, karena proses peradilan pada hakikatnya suatu proses menegakkan hukum. Jadi pada hakikatnya identik dengan "sistem kekuasaan kehakiman", karena "kekuasaan kehakiman" pada dasarnya merupakan "kekuasaan/ kewenangan menegakkan hukum". ${ }^{3}$ Sistem peradilan pidana merupakan kekuasaan menegakkan hukum pidana yang terdiri dari empat lembaga atau institusi yaitu penyidikan, penuntutan, mengadili dan lembaga pelaksana putusan. Salah satu lembaga kekuasaan kehakiman atau sub sistem menegakkan hukum pidana adalah kekuasaan penuntutan yang dilakukan oleh kejaksaan. Pimpinan dan penanggung jawab tertinggi kejaksaan adalah jaksa agung, sebagaimana tercantum dalam Undang-Undang Nomor 16 Tahun 2004 tentang Kejaksaan Republik Indonesia Pasal 18 ayat (1) yang menentukan bahwa jaksa agung adalah pimpinan dan penanggung jawab tertinggi kejaksaan yang memimpin, mengendalikan pelaksanaan tugas, dan wewenang kejaksaan. Salah satu tugas dan wewenang jaksa agung adalah mengesampingkan perkara demi

\footnotetext{
${ }^{1}$ Satjipto Rahardjo, "Sosiologi Hukum Perkembangan Metode dan Pilihan Masalah", Surakarta: Muhammadiyah University Press, 2004, hal 60.

${ }^{2}$ Kaelan, Filsafat Pancasila Pandangan Hidup Bangsa Indonesia, (Yogyakarta: Paradigma, 2009), hal 132.

${ }^{3}$ Barda Nawawi Arief, "Reformasi Sistem Peradilan (Sistem Penegakan Hukum) di Indonesia”, Semarang: Badan Penerbit Universitas Diponegoro, 2012, hal 3.
} 
kepentingan umum, yang diatur dalam Undang-Undang Nomor 16 Tahun 2004 tentang Kejaksaan Republik Indonesia, Pasal 35 huruf c.

Dalam Penjelasan Pasal 35 huruf c disebutkan bahwa yang dimaksud dengan "kepentingan umum" adalah kepentingan bangsa dan negara dan/atau kepentingan masyarakat luas. Mengesampingkan perkara sebagaimana dimaksud dalam ketentuan ini merupakan pelaksanaan asas oportunitas, yang hanya dapat dilakukan oleh Jaksa Agung setelah memperhatikan saran dan pendapat dari badan-badan kekuasaan negara yang mempunyai hubungan dengan masalah tersebut. Seponering adalah hak istimewa Jaksa Agung untuk mengesampingkan perkara atau memetieskan suatu perkara karena alasan kepentingan umum setelah mendapat saran atau masukan dari institusi terkait di bidang hukum. ${ }^{4}$ Berdasarkan Penjelasan Pasal 35 huruf c, bahwa "kepentingan umum" adalah kepentingan bangsa dan negara dan/atau kepentingan masyarakat luas. Mengenai pengertian kepentingan bangsa dan negara dan/atau kepentingan masyarakat, tidak ada uraian lebih lanjut dalam Penjelasan tersebut.

Kajian sebelumnya mengenai pengesampingan perkara oleh Yeni Handayani (2016) dengan judul "Jaksa Agung Dan Pengesampingan Perkara Demi Kepentingan Umum", yang menjelaskan bahwa untuk menjamin kepastian hukum dalam rangka pelaksanaan asas oportunitas, Jaksa Agung menuangkan dalam suatu surat penetapan/keputusan yang salinannya diberikan kepada yang dikesampingkan perkaranya demi kepentingan umum, hal mana dapat dipergunakan sebagai alat bukti bagi yang bersangkutan. Terhadap perkara yang dikesampingkan demi kepentingan umum, penuntut umum tidak berwenang melakukan penuntutan terhadap tersangka. Dengan demikian kriteria demi kepentingan umum dalam penerapan asas oportunitas didasarkan untuk kepentingan negara dan masyarakat dan bukan untuk kepentingan pribadi. Pengaturan asas oportunitas menjadi kepentingan di dalam sistem peradilan

${ }^{4}$ Damiri Hasan, "Diskresi Seponering Dalam Perspektif Hukum Islam:Studi Kasus Pidana Korupsi Bibit Samad Rianto dan Chandra Martha Hamzah", Intizar 22(1), 2016, hal 38. https://doi.org/10.19109/intizar.v22i1.544 
pidana khususnya di Indonesia agar aturan mengenai asas oportunitas yang sesuai dengan Pasal 35 huruf c UU Kejaksaan Tahun 2004 tidak menjadi aturan yang disalahgunakan oleh instansi atau lembaga-lembaga yang ada. ${ }^{5}$

Hasil kajian yang lain disampaikan oleh Sri Mulyati Chalil (2018) dengan judul "Pengesampingan Perkara (Deponering) Oleh Jaksa Agung". Kajian tersebut menjelaskan bahwa pengesampingan perkara (deponering) merupakan penerapan atau pelaksanaan asas oportunitas yangdimiliki oleh Jaksa Agung sebagai penuntut umum tertinggi yang diatur di dalam undang-undang. Konsep kepentingan umum yang menjadi alasan jaksa dalam mendeponering kasus Abraham Samad dan Bambang Widjojanto dalam Penjelasan Pasal 35 huruf c UU No16 Tahun 2004 tentang Kejaksaan tidaklah memiliki tolak ukur yang pasti apa yang disebut dengan kepentingan umum secara jelas. Pemberian deponering yang dilakukan oleh jaksa agung tidak sesuai dengan asas yang berlaku di KUHAP berakibat memberikan perbedaan di hadapan hukum yaitu sebagaimana dalam konsep yang dianut oleh negara hukum yaitu equality before the law yang diatur juga di dalam UUD 1945 sebagai payung hukum di Indonesia Sistem hukum yang teramputasi tersebut tentu tidak menunjang kepada terciptanya tujuan dari sebuah hukum itu dibentuk dan diberlakukan, sehingga cita-cita hukum akan sulit untuk dapat terlaksana. ${ }^{6}$

Kiki Astuti Wulandary Sutin (2020) dalam penelitiannya yang berjudul "Kewenangan Jaksa Agung Dalam Mengesampingkan Perkara Demi Kepentingan Umum" lebih fokus mengkaji mengenai pengesampingan perkara demi kepentingan umum terhadap Abraham Samad dan Bambang Widjojanto dengan pertimbangan Jaksa Agung terkait aspek filosofis dan yuridis. Setelah dianalisis lebih lanjut terkait pertimbangan Jaksa Agung

${ }^{5}$ Yeni Handayani, “Jaksa Agung Dan Pengesampingan Perkara Demi Kepentingan Umum”. Jurnal RechtsVinding, 2016, hal. 1-7.

${ }^{6}$ Sri Mulyati Chalil, "Pengesampingan Perkara (Deponering) Oleh Jaksa Agung” Wacana Paramarta: Jurnal Ilmu Hukum, 15(1), hal 1-10. 
tersebut, maka keputusan untuk mengesampingkan perkara terhadap Abraham Samad dan Bambang Widjojanto belum menunjukkan terganggunya kepentingan umum secara nyata yakni kepentingan negara dan/atau kepentingan masyarakat luas. ${ }^{7}$

Penelitian ini melengkapi kajian sebelumnya dengan tema yang sama, dengan fokus permasalahan bagaimana pengesampingan perkara demi kepentingan umum dilaksanakan setelah adanya putusan Mahkamah Konstitusi Nomor 29/PUU-XIV/2016 dengan tidak melihat hanya satu putusan tertentu yang dapat dikenakan pengesampingan perkara demi kepentingan umum. Hal ini berbeda dengan penelitian sebelumnya yang hanya fokus mengkaji mengenai pengesampingan perkara demi kepentingan umum pada kasus pimpinan Komisi Pemberantasan Korupsi Abraham Samad dan Bambang Widjojanto. Sedangkan yang dikaji dalam penelitian ini lebih bersifat umum mengenai pengesampingan perkara pasca putusan Mahkamah Konstitusi. Tujuan dari penelitian ini adalah menganalisis pengesampingan perkara demi kepentingan umum pascaputusan Mahkamah Konstitusi Nomor 29/PUU-XIV/2016.

\section{B. Perumusan Masalah}

Permasalahan dalam penelitian ini difokuskan pada:

1. Bagaimana pengesampingan perkara demi kepentingan umum sebagai pelaksanaan asas oportunitas dalam penuntutan?

2. Bagaimana pengesampingan perkara demi kepentingan umum pascaputusan Mahkamah Konstitusi Nomor 29/PUU-XIV/2016?

\section{Metode Penelitian}

Jenis penelitian yang digunakan adalah yuridis normatif, yang meletakkan hukum sebagai sebuah bangunan sistem norma. Sistem norma yang dimaksud adalah mengenai asas-asas, norma, kaidah dari peraturan perundang-undangan,

7 Kiki Astuti Wulandary Suti, "Kewenangan Jaksa Agung Dalam Mengesampingkan Perkara Demi Kepentingan Umum”, Kalabbirang Law Journal 2(2), 2020, hal 138-151. 
putusan pengadilan, perjanjian serta doktrin (ajaran). ${ }^{8}$ Spesifikasi penelitian dilakukan secara deskriptif analitis. Teknik pengumpulan data dilakukan dengan studi pustaka dan studi dokumen, dengan sumber data utama yang digunakan adalah data sekunder. Metode analisis data dilakukan secara kualitatif normatif.

\section{PEMBAHASAN}

\section{Pengesampingan Perkara demi Kepentingan Umum Sebagai Pelaksanaan Asas Oportunitas dalam Penuntutan.}

Asas dalam penuntutan ada dua yaitu asas legalitas dan asas oportunitas. Secara sederhana, dalam penuntutan berasaskan legalitas, jaksa wajib menuntt segala perbuatan yang dapat dipidana yang dilakukan oleh tersangka. Sedangkan dalam penuntutan berasaskan oportunitas, jaksa tidak diwajibkan menuntut segala perbuatan yang dapat dipidana yang dilakukan oleh tersangka. ${ }^{9}$ Indonesia merupakan negara yang menganut asas oportunitas dalam hal penuntutan. Kasus yang tidak dilakukan penuntutan atau telah dikesampingkan demi kepentingan umum oleh Jaksa Agung, di antaranya kasus Bibit S Rianto dan Chandra M Hamzah. Jaksa Agung Basrief Arief resmi menerbitkan deponeering atau pengesampingan perkara dua pimpinan Komisi Pemberantasan Korupsi (KPK) Bibit S Rianto dan Chandra M Hamzah. Surat pengesampingan perkara demi kepentingan umum itu bernomor TAP 001/A/JA/01/2011 atas nama Chandra Marta Hamzah, dan TAP 002/a/JA/01/2011 atas nama Dr. Bibit Samad Rianto. 10 Pengesampingan perkara yang lain adalah kasus yang menjerat mantan pimpinan Komisi Pemberantasan Korupsi Abraham Samad dan Bambang Widjojanto. Menurut Prasetyo, deponering diberikan dengan alasan kasus

\footnotetext{
${ }^{8}$ Mukti Fajar ND dan Yulianto Achmad, "Dualisme Penelitian Hukum Normatif dan Empiris”, Yogyakarta: Pustaka Pelajar,2013, hal 34.

${ }^{9}$ Andi Hamzah, RM Surachman, "Pre-Trial Justice Discretionary Justice Dalam KUHAP Berbagai Negara”, (Jakarta: Sinar Grafika, 2015), hal 208.

10 Jaksa Agung Resmi Terbitkan Deponeering, https://nasional.kompas.com/read/2011/01/24/20210150/Jaksa.Agung.Resmi.Terbitkan Deponeering (diakses 23 Desember 2019).
} 
Abraham Samad dan Bambang Widjojanto merupakan perkara luar biasa. Kasus keduanya dihentikan karena amat menyita perhatian publik dan dikhawatirkan dapat memperlemah semangat pemberantasan korupsi di Indonesia jika dilanjutkan proses hukumnya. ${ }^{11}$ Komisi III DPR RI telah memberi rekomendasi kepada pimpinan DPR untuk menyatakan pendapat atas penanganan kasus Abraham dan Bambang. Substansi rekomendasi yaitu menolak usul dari Jaksa Agung terkait deponering bagi dua mantan Pimpinan KPK tersebut. Komisi III menilai syarat deponering yakni menyangkut kepentingan umum belum terpenuhi. ${ }^{12}$

Ketentuan Pasal 35 huruf c Undang-Undang Nomor 16 Tahun 2004 tentang Kejaksaan Republik Indonesia berikut penjelasannya dapat menimbulkan ketidakadilan dan tidak adanya kepastian hukum bagi korban atau pihak yang bersangkutan apabila kasusnya dihentikan. Sebagai contoh di antaranya kasus pencurian sarang burung walet yang telah diputus oleh pengadilan dan para pelaku telah menjalani masa hukumannya. Wewenang yang dimiliki Jaksa Agung itu sangat rentan akan disalahgunakan sebagai alat untuk memberikan kekebalan hukum terhadap pihak-pihak tertentu yang akhirnya menyebabkan pelanggaran dan kerugian hak konstitusional Para Pemohon. ${ }^{13}$ Para pemohon yaitu Irwansyah Siregar dan Dedi Nuryadi merasa dirugikan hak konstitusionalnya sebagai warga negara dengan adanya ketentuan Pasal 35 huruf c Undang-Undang Nomor 16 Tahun 2004 tentang Kejaksaan Republik Indonesia berikut penjelasannya. Kasus penganiayaan pencuri burung walet (yang diduga dilakukan NB) yang terjadi pada 18

\footnotetext{
${ }^{11}$ Lalu Rahadian, "Jaksa Agung Deponering Kasus Abraham Samad- Bambang Widjojanto", CNN Indonesia | Kamis, 03/03/2016 17:06 WIB, https://www.cnnindonesia.com/nasional/20160303170657-12-115183/jaksa-agungdeponering-kasus-abraham-samad-bambang-widjojanto? (diakses 28 Agustus 2019).

${ }^{12}$ Prianter Jaya Hairi, "Pengesampingan Perkara Pidana Abraham Samad dan Bambang Widjojanto", Info Singkat Hukum 8(4), 2016, hal 2.

13“Kewenangan Seponering Jaksa Agung Diperketat”, Majalah Konstitusi 120, 2017, hal. 19.
} 
Februari 2004. Perkara dilimpahkan oleh jaksa penuntut umum pada tanggal 29 Januari 2016. Namun setelah ditetapkan hari sidang, jaksa penuntut umum menarik surat dakwaan dengan alasan untuk diperbaiki atau disempurnakan. Alih-alih memperbaiki atau menyempurnakan surat dakwaan, jaksa penuntut umum justru mengeluarkan Surat Ketetapan Penghentian Penuntutan No. Kep B.03/N.7.10/Ep.1/02/2016 tanggal 22 Februari 2016 (SKP2) untuk menghentikan penuntutan dalam kasus tersebut dengan alasan tidak cukup bukti dan sudah daluwarsa. 14 Hakim Praperadilan pun telah memutuskan SKPP Novel tidak sah. ${ }^{15}$ Praperadilan diajukan di Pengadilan Negeri Bengkulu pada tanggal 1 Maret 2016, sebagaimana dengan nomor perkara 02/PID.PRA/2016/PN. Bgl dan pada tanggal 31 Maret 2016 Pengadilan Negeri Bengkulu telah mengeluarkan putusan yang pada intinya menyatakan SKP2 tidak sah. ${ }^{16}$ Irwansyah Siregar dan Dedi Nuryadi (pemohon) merasa dirugikan hak konstitusionalnya dan mengajukan pengujian Undang-Undang Nomor 16 Tahun 2004 tentang Kejaksaan Republik Indonesia Pasal 35 huruf c beserta Penjelasannya ke Mahkamah Konstitusi terhadap Pasal 28A, 28D ayat (1) dan Pasal 28I ayat (1) dan (2) Undang-Undang Dasar Negara Republik Indonesia Tahun 1945. Dalam Putusan Nomor 29/PUU-XIV/2016 berkaitan dengan pokok permohonan, Mahkamah Konstitusi memutuskan :

Menyatakan frasa "mengesampingkan perkara sebagaimana dimaksud dalam ketentuan ini merupakan pelaksanaan atas asas oportunitas yang hanya dapat dilakukan oleh Jaksa Agung setelah memperhatikan saran dan pendapat dari badan-badan kekuasaan negara yang mempunyai hubungan dengan masalah tersebut" dalam Penjelasan Pasal 35 huruf c UndangUndang Nomor 16 Tahun 2004 tentang Kejaksaan Republik Indonesia (Lembaran Negara Republik Indonesia Tahun 2004 Nomor 67 dan Tambahan

14 Putusan MK Nomor 29/PUU-XIV/2016, hal. 4.

15 "Begini Ahli KUHAP Maknai Seponering 'Demi Kepentingan Umum'”, https://www.hukumonline.com/berita/baca/lt5731c8f006059/begini-ahli-kuhap-maknaiiseponering-i-demi-kepentingan-umum (diakses 29 Agustus 2019).

16 Putusan MK Nomor 29/PUU-XIV/2016, hal. 5. 
Lembaran Negara Republik Indonesia Nomor 4401) bertentangan dengan Undang-Undang Negara Republik Indonesia Tahun 1945 secara bersyarat dan tidak mempunyai kekuatan hukum mengikat sepanjang tidak dimaknai Jaksa Agung wajib memperhatikan saran dan pendapat dari badan-badan kekuasaan negara yang mempunyai hubungan dengan masalah tersebut;

Hakim Mahkamah Konstitusi dalam putusannya menentukan bahwa Penjelasan Pasal 35 huruf c Undang-Undang Nomor 16 Tahun 2004 tentang Kejaksaan Republik Indonesia, harus dimaknai bahwa Jaksa Agung wajib memperhatikan saran dan pendapat dari badan-badan kekuasaan negara yang mempunyai hubungan dengan masalah tersebut. Seponering merupakan pelaksanaan dari asas oportunitas yang dianut Indonesia. Pelaksanaan seponering membuka peluang pelanggaran hak khususnya berkaitan dengan ketentuan dalam Undang-Undang Nomor 16 Tahun 2004 tentang Kejaksaan Republik Indonesia Pasal 35 huruf c beserta Penjelasannya. Pengesampingan perkara setelah Putusan Mahkamah Konstitusi Nomor 29/PUU-XIV/2016, penting dikaji berkaitan dengan kewajiban Jaksa Agung memperhatikan saran dan pendapat dari badan-badan kekuasaan negara.

Dua asas penuntutan yaitu pertama asas legalitas, dimana jaksa wajib melakukan penuntutan terhadap segala perbuatan yang dapat dipidana yang dilakukan oleh tersangka, disebut juga asas mandatory prosecution. Kedua, asas oportunitas dimana jaksa tidak diwajibkan menuntut segala perbuatan yang dapat dipidana yang dilakukan oleh tersangka, atau disebut juga asas discretionary prosecution atau penuntutan berdasarkan asas kelayakan (the principle of expediency), biasanya dikaitkan dengan kepentingan umum. ${ }^{17}$ Asas oportunitas adalah asas hukum yang memberikan wewenang kepada penuntut umum untuk menuntut dan tidak menuntut dengan syarat atau tanpa syarat seseorang atau korporasi yang telah mewujudkan delik demi kepentingan umum. ${ }^{18}$

17 Andi Hamzah-RM Surachman, Loc. Cit.

18 Yeni Handayani, Op.Cit, hal. 3. 
Di beberapa negara penganut asas oportunitas, telah berkembang penyampingan perkara tidak hanya berdasarkan kepentingan umum, namun atas pertimbangan yang bervariasi dalam rangka diskresi penuntutan. ${ }^{19}$ Belanda sebagai salah satu negara yang menganut asas oportunitas dalam penuntutan, menggunakan diskresi penuntutan yaitu penghentian penuntutan dalam hal tindak pidana yang dilakukan mempunyai cukup bukti untuk dilakukan penuntutan. Penghentian penuntutan tersebut dengan alasan kebijakan di antaranya karena tindak pidana yang ringan, bukan pengulangan tindak pidana, usia dari pelaku yang sangat tua atau karena ada ganti kerugian terhadap korban. Dalam bahasa sehari-hari tindakan tersebut dikenal sebagai “mengesampingkan perkara" (penerapan sepot atau menseponir), yaitu menghentikan penuntutan karena alasan kebijakan. Belakangan dalam Bahasa Inggris dikenal sebagai public interest drop. ${ }^{20}$

Mengesampingkan perkara (seponering) demi kepentingan umum merupakan kewenangan jaksa penuntut umum (di Indonesia oleh Jaksa Agung) sebagai pelaksanaan asas di bidang penuntutan yaitu asas oportunitas. Seponeren digunakan dalam perkara pidana dalam arti menyampingkan, tidak diadakan penuntutan (oleh penuntut umum berdasarkan asas oportunitas, atau bukti yang ada tidak cukup lengkap untuk mengadakan tuntutan hukum). Asal kata sepot berarti penyampingan, penyisihan. ${ }^{21}$ Asas legalitas dipahami sebagai asas yang mempunyai pengertian bahwa penuntut umum diwajibkan untuk melakukan penuntutan terhadap seseorang yang melakukan tindak pidana dimana asas legalitas ini merupakan perwujudan dari asas equality before the law, sedangkan asas oportunitas memberikan wewenang kepada penuntut umum untuk tidak melakukan penuntutan terhadap seseorang yang melanggar peraturan hukum pidana dengan jalan mengesampingkan perkara yang sudah ada terang

19 Darmono, "Penyampingan Perkara Pidana Seponering dalam Penegakan Hukum", Jakarta: Solusi Publishing, 2013, hal. 56.

20 Andi Hamzah-RM Surachman, Op.cit, hal. 240.

21 Darmono, Op. Cit., hal. 48. 
pembuktiannya untuk kepentingan umum. Dikarenakan bahwa asas legalitas merupakan perwujudan dari asas equality before the law maka sebenarnya kedua asas tersebut bertolak belakang dengan asas oportunitas yang berarti sekalipun seorang tersangka sudah jelas cukup bersalah menurut pemeriksaan penyidikan, dan kemungkinan besar akan dapat dijatuhi hukuman, namun hasil pemeriksaan tersebut tidak dilimpahkan ke sidang pengadilan oleh penuntut umum. Proses perkara itu "seponering” oleh pihak kejaksaan atas dasar pertimbangan "demi kepentingan umum". ${ }^{22}$

Indonesia merupakan penganut asas oportunitas, dimana tidak semua perkara dapat dilakukan penuntutan, melainkan dapat dikesampingkan dengan alasan kepentingan umum. Perkara pidana yang dikesampingkan tersebut mempunyai alat bukti yang cukup dan dapat dilakukan penuntutan, namun tidak dilakukan penuntutan dengan alasan demi kepentingan umum. Diskresi penuntutan pada prinsipnya merupakan keputusan jaksa penuntut umum yang didasarkan pada pertimbangan tertentu mengambil keputusan untuk tidak melanjutkan penuntutan ke pengadilan. Pertimbanganpertimbangan yang diambil merupakan kebijaksanaan yang didasarkan pada keadilan dan tidak terikat pada ketentuan perundang-undangan.

Pada dasarnya asas oportunitas memberikan pilihan pada jaksa penuntut umum untuk menuntut perkara tersebut atau mengesampingkannya sehingga tidak dilakukan penuntutan. Pengesampingan perkara sebagai kewenangan penuntut umum pada akhirnya dalam Undang-Undang Kejaksaan (sejak Undang-Undang Nomor 15 Tahun 1961 tentang Kejaksaan RI) dialihkan menjadi kewenangan Jaksa Agung. Hal ini dilakukan agar tidak terjadi penyalahgunaan wewenang dan hanya dikhususkan pada kasus-kasus tertentu yang menyangkut kepentingan umum, sehingga dengan demikian diperlukan batasan dalam melakukan pengesampingan perkara demi kepentingan umum. Setelah wewenang mengesampingkan perkara diambil

\footnotetext{
${ }^{22}$ Muhamad Iqbal, “Implementasi Efektifitas Asas Oportunitas Di Indonesia Dengan Landasan Kepentingan Umum”, Jurnal Surya Kencana 9(1), 2018, hal. 98 http://dx.doi.org/10.32493/jdmhkdmhk.v9i1.1178
} 
oleh Jaksa Agung, kini para jaksa di Indonesia hanya memiliki wewenang menghentikan penuntutan karena alasan teknis yaitu tidak cukup bukti, peristiwanya bukan merupakan tindak pidana dan perkara ditutup demi hukum. ${ }^{23}$

Pasal 35 huruf c Undang-Undang Nomor 16 Tahun 2004 tentang Kejaksaan Republik Indonesia merupakan dasar hukum mengesampingkan perkara demi kepentingan umum sebagai kewenangan Jaksa Agung. Perkara yang dikesampingkan dalam hal ini mempunyai bukti yang cukup, namun berkaitan dengan kepentingan umum menghendaki untuk tidak dilakukan penuntutan. Keberadaan asas oportunitas tersebut adalah untuk melihat suatu perkara tersebut layak dilakukan penuntutan atau tidak dengan melihat bukan saja dari sudut pandang sebab akibatnya perkara melainkan dari sudut pandang kepentingan umum. ${ }^{24}$

Kepentingan umum dalam Penjelasan Pasal 35 huruf c UndangUndang Nomor 16 Tahun 2004 tentang Kejaksaan Republik Indonesia adalah kepentingan bangsa dan negara dan/atau kepentingan masyarakat luas. Pengertian tersebut belum memberikan penjelasan dengan ukuran atau ketentuan yang konkrit sehingga dapat menimbulkan penafsiran yang berbeda-beda. Tidak adanya penjelasan lebih lanjut atau secara khusus mengenai kepentingan umum adalah dimungkinkan lebih bijaksana, hal ini berkaitan dengan adanya keadaan-keadaan konkrit yang bermacam-macam yang terjadi dalam praktek, tidak dapat disebut satu per satu hal-hal yang masuk dalam kepentingan umum dan sangat sulit mengadakan aturan-aturan umum tentang apa yang dimaksud kepentingan umum dalam asas oportunitas. $^{25}$

\footnotetext{
${ }^{23}$ Darmono, Op. Cit., hal. 61.

${ }^{24}$ Tumpal Napitupulu, "Penerapan Azas Oportunitas Berhubungan dengan Tugas dan Wewenang Kejaksaan dalam Sistem Peradilan Pidana (Kajian Perkara Terhadap Terdakwa Novel bin Salim Baswedan)", Tanjungpura Law Journal 2(1), 2018, hal 121. http://dx.doi.org/10.26418/tlj.v2i1.32679

${ }^{25}$ Darmono, Op. Cit., hal 77.
} 
Pengesampingan perkara sebagai pelaksanaan asas oportunitas merupakan kewenangan Jaksa Agung yang dilakukan demi kepentingan umum melalui pertimbangan kebijakan yang didasarkan pada keadilan. Kewenangan pengesampingan perkara demi kepentingan umum oleh Jaksa Agung ditujukan agar tidak ada penyalahgunaan wewenang oleh jaksa penuntut umum. Dengan demikian kewenangan mengenyampingkan perkara dengan alasan teknis merupakan kewenangan jaksa penuntut umum, sedangkan kewenangan mengenyampingkan perkara demi kepentingan umum merupakan kewenangan Jaksa Agung dengan pertimbangan kebijakan dan dilakukan terhadap kasus-kasus tertentu.

Tugas menyampingkan perkara hanya dapat dilakukan oleh Jaksa Agung dan bukan oleh Jaksa di bawah Jaksa Agung. Jaksa Agung dapat menyampingkan perkara setelah memperhatikan saran dan pendapat dari badan-badan kekuasaan negara yang mempunyai hubungan dengan masalah tersebut. $^{26}$

Pengesampingan perkara demi kepentingan umum sebagai pelaksanaan asas oportunitas dalam penuntutan memberikan pilihan pada jaksa penuntut umum untuk menuntut perkara tersebut atau mengesampingkannya sehingga tidak dilakukan penuntutan. Di Indonesia pengesampingan perkara demi kepentingan umum sebagai pelaksanaan asas oportunitas merupakan kewenangan Jaksa Agung yang hanya dapat dilakukan setelah memperhatikan saran dan pendapat dari badan-badan kekuasaan negara terkait.

\section{Pengesampingan Perkara demi Kepentingan Umum Pascaputusan Mahkamah Konstitusi Nomor 29/PUU-XIV/2016}

Kekuasaan kehakiman merupakan kekuasaan yang menyelenggarakan peradilan yang dilakukan oleh sebuah Mahkamah Agung dan badan peradilan

\footnotetext{
${ }^{26}$ Ferdy Saputra et. al., "Analisis Yuridis Penerbitan Surat Perintah Penghentian Penuntutan Oleh Kejaksaan Dikaitkan Dengan Azas Oportunitas dan UndangUndang No. 16 Tahun 2004 Tentang Kejaksaan RI”, Jurnal Fakultas Hukum, Universitas Sumatra Utara, 2(1), 2014, hal.105-123.
} 
yang berada di bawahnya dalam lingkungan peradilan umum, lingkungan peradilan agama, lingkungan peradilan militer, lingkungan peradilan tata usaha negara, dan oleh sebuah Mahkamah Konstitusi, sebagaimana ditentukan Undang-Undang Dasar Negara Republik Indonesia Tahun 1945 dalam Pasal 24. Mahkamah Konstitusi mempunyai kewenangan menguji undang-undang terhadap Undang-Undang Dasar sesuai Pasal 24C ayat (1) Undang-Undang Dasar Negara Republik Indonesia Tahun 1945 yang menentukan bahwa Mahkamah Konstitusi berwenang mengadili pada tingkat pertama dan terakhir yang putusannya bersifat final untuk menguji undangundang terhadap Undang-Undang Dasar, memutus sengketa kewenangan lembaga negara yang kewenangannya diberikan oleh Undang-Undang Dasar, memutus pembubaran partai politik dan memutus perselisihan tentang hasil pemilihan umum. Kewenangan Mahkamah Konstitusi tersebut dijabarkan dalam Undang-Undang Nomor 24 Tahun 2003 tentang Mahkamah Konstitusi yang telah diubah dengan Undang-Undang Nomor 8 Tahun 2011 tentang Perubahan Atas Undang-Undang Nomor 24 Tahun 2003 tentang Mahkamah Konstitusi, Pasal 10 ayat (1) huruf a yang menentukan bahwa Mahkamah Konstitusi berwenang mengadili pada tingkat pertama dan terakhir yang putusannya bersifat final untuk menguji undang-undang terhadap UndangUndang Dasar Negara Republik Indonesia Tahun 1945.

Kejaksaan Republik Indonesia termasuk salah satu badan yang fungsinya berkaitan dengan kekuasaan kehakiman menurut Undang-Undang Dasar Negara Republik Indonesia Tahun 1945, sebagaimana tercantum dalam bagian Menimbang huruf b Undang-Undang Nomor 16 Tahun 2004 tentang Kejaksaan Republik Indonesia. Penuntutan menurut KUHAP dan UndangUndang Nomor 16 Tahun 2004 tentang Kejaksaan Republik Indonesia, merupakan tindakan penuntut umum melimpahkan perkara ke pengadilan negeri sesuai dengan hukum acara yang berlaku dengan permintaan supaya diperiksa dan diputus oleh hakim di sidang pengadilan. Pelaksanakan fungsi dan wewenang penuntutan tersebut, pada suatu pihak menerima berkas perkara hasil pemeriksaan penyidikan dari penyidik dan pada pihak lain, 
berkas perkara yang diterimanya dilimpahkan kepada hakim untuk dituntut dan diperiksa dalam sidang pengadilan. ${ }^{27}$

Jaksa Agung merupakan pimpinan dan penanggung jawab tertinggi kejaksaan mempunyai tugas dan wewenang yang diatur dalam UndangUndang. Kewenangan Jaksa Agung di antaranya mengesampingkan perkara demi kepentingan umum dengan dasar hukum Pasal 35 huruf c UndangUndang Nomor 16 Tahun 2004 tentang Kejaksaan Republik Indonesia, di satu pihak merupakan kebijakan yang diambil demi kepentingan umum, di lain pihak bagi orang yang berkepentingan merupakan pelanggaran terhadap hak yang dilindungi oleh konstitusi. Dalam Putusan Mahkamah Konstitusi Nomor 29/PUU-XIV/2016, para pemohon (Irwansyah Siregar dan Dedi Nuryadi) adalah orang yang merasa haknya telah dilanggar oleh ketentuan Pasal 35 huruf c Undang-Undang Nomor Nomor 16 Tahun 2004 tentang Kejaksaan Republik Indonesia beserta Penjelasannya. Para pemohon sebagai korban penganiayaan (yang diduga dilakukan oleh NB) merasa dirugikan, dilanggar haknya dan diperlakukan secara diskriminatif dengan adanya ketentuan pengesampingan perkara demi kepentingan umum sebagaimana ketentuan Pasal 35 huruf c Undang-Undang Nomor Nomor 16 Tahun 2004 tentang Kejaksaan Republik Indonesia beserta Penjelasannya. Para pemohon merasa hak konstitusionalnya dilanggar khususnya Pasal 28A, Pasal 28D ayat (1), Pasal 28I ayat (1) dan (2) Undang-Undang Dasar Negara Republik Indonesia Tahun 1945. Berikut ketentuan pasal-pasal tersebut :

a. Pasal 28A : Setiap orang berhak untuk hidup serta berhak mempertahankan hidup dan kehidupannya.

b. Pasal 28D ayat (1) : Setiap orang berhak atas pengakuan, jaminan, perlindungan, dan kepastian hukum yang adil serta perlakuan yang sama di hadapan hukum.

${ }^{27}$ M. Yahya Harahap, "Pembahasan Permasalahan dan Penerapan KUHAP Penyidikan dan Penuntutan”, Jakarta: Sinar Grafika, 2010, hal. 367. 
c. Pasal 28I ayat (1) dan (2) :

(1)Hak untuk hidup, hak untuk tidak disiksa, hak untuk kemerdekaan pikiran dan hati nurani, hak beragama, hak untuk tidak diperbudak, hak untuk diakui sebagai pribadi di hadapan hukum, dan hak untuk tidak dituntut atas dasar hukum yang berlaku surut adalah hak asasi manusia yang tidak dapat dikurangi dalam keadaan apapun.

(2)Setiap orang bebas dari perlakuan yang bersifat diskriminatif atas dasar apapun dan berhak mendapatkan perlindungan terhadap perlakuan yang bersifat diskriminatif itu.

Pertimbangan Mahkamah Konstitusi dalam Putusan Nomor 29/PUUXIV/2016 berkaitan dengan pokok permohonan di antaranya: bahwa asas oportunitas tidak dimaksudkan untuk mengabaikan atau menghilangkan hak konstitusional warga negara yang dijamin Undang-Undang Dasar Negara Republik Indonesia Tahun 1945. Pemilihan asas oportunitas atau asas legalitas atau tidak memilih keduanya merupakan pilihan pembentuk undangundang. Indonesia dalam sistem hukumnya memilih asas oportunitas, sehingga pilihan tersebut merupakan pilihan yang tidak bertentangan dengan Undang-Undang Negara Republik Indonesia Tahun 1945. Pertimbangan selanjutnya disebutkan bahwa wewenang Jaksa Agung untuk melakukan seponering adalah wewenang yang diberikan oleh Undang-Undang Nomor 16 Tahun 2004 tentang Kejaksaan Republik Indonesia, sehingga mempunyai dasar hukum dalam pelaksanaannya. Wewenang seponering tersebut merupakan pelaksanaan asas oportunitas yang merupakan bagian dari asas diskresi (freies ermesen) Jaksa Agung untuk menuntut atau tidak menuntut perkara. Kewenangan seponering tidak dimaksudkan untuk menghilangkan hak atas pengakuan, jaminan, perlindungan dan kepastian hukum yang adil serta perlakuan yang sama di hadapan hukum (Pasal 28D ayat (1) UndangUndang Negara Republik Indonesia Tahun 1945) dan tidak pula untuk memperlakukan secara diskriminatif antara warga negara yang satu dengan yang lainnya. Undang-Undang Negara Republik Indonesia Tahun 1945 tidak menentukan pasal yang memberikan kewenangan atau sebagai dasar 
pembenar untuk dapat diterapkannya asas oportunitas dalam penegakan hukum di Indonesia, akan tetapi bukan berarti penerapan asas oportunitas bertentangan dengan Undang-Undang Negara Republik Indonesia Tahun 1945. Menurut Mahkamah Konstitusi seponering yang merupakan pelaksanaan asas oportunitas tidak bertentangan dengan Undang-Undang Negara Republik Indonesia Tahun 1945 meskipun tidak diatur secara eksplisit dalam pasal-pasalnya. Selanjutnya Mahkamah Konstitusi memberikan penafsiran terhadap Penjelasan Pasal 35 huruf c UndangUndang Nomor 16 Tahun 2004 tentang Kejaksaan Republik Indonesia agar tidak bertentangan dengan Undang-Undang Negara Republik Indonesia Tahun 1945 yaitu frasa "setelah memperhatikan saran dan pendapat dari badan-badan kekuasaan negara yang mempunyai hubungan dengan masalah tersebut" harus dimaknai "Jaksa Agung wajib memperhatikan saran dan pendapat dari badan-badan kekuasaan negara yang mempunyai hubungan dengan masalah tersebut”. Penafsiran terhadap Penjelasan Pasal 35 huruf c tersebut dibutuhkan agar ada ukuran yang jelas dan ketat dalam penggunaan kewenangan pengesampingan perkara demi kepentingan umum atau seponering oleh Jaksa Agung, karena terhadap kewenangan seponering tersebut tidak terdapat upaya hukum lain untuk membatalkannya kecuali Jaksa Agung itu sendiri. ${ }^{28}$

Undang-Undang Negara Republik Indonesia Tahun 1945 tidak mengatur secara eksplisit pasal yang secara khusus memberikan kewenangan atau sebagai dasar untuk dapat diterapkannya asas oportunitas, meskipun demikian pengesampingan perkara tersebut tidak bertentangan dengan Undang-Undang Negara Republik Indonesia Tahun 1945. Pengesampingan perkara sebagai pelaksanaan asas oportunitas hanya diberikan demi kepentingan umum. Pengenyampingkan perkara demi kepentingan umum perlu diberikan pembatasan atau ketentuan yang ketat mengenai pengertian

28 Putusan MK Nomor 29/PUU-XIV/2016. 
kepentingan umum, karena kewenangan tersebut sangat rentan untuk diartikan sesuai dengan karena kepentingan Jaksa Agung, meskipun dalam menerapkan seponering dalam Penjelasan Pasal 35 huruf c dinyatakan "hanya dapat dilakukan oleh Jaksa Agung setelah memperhatikan saran dan pendapat dari badan-badan kekuasaan negara yang mempunyai hubungan dengan masalah tersebut." Frasa "hanya dapat" memberikan pemahaman sebagai kewajiban Jaksa Agung untuk memperhatikan saran dan pendapat dari badanbadan kekuasaan negara yang mempunyai hubungan dengan masalah tersebut, sehingga seponering dapat dilakukan "setelah memperhatikan saran dan pendapat...". Selanjutnya kata "memperhatikan" memberikan pengertian bahwa tidak ada kewajiban bagi Jaksa Agung untuk mengikuti saran dan pendapat dari badan-badan kekuasaan negara yang mempunyai hubungan dengan masalah tersebut.

Putusan Mahkamah Konstitusi Nomor 29/PUU-XIV/2016 yang menyatakan frasa "mengesampingkan perkara sebagaimana dimaksud dalam ketentuan ini merupakan pelaksanaan atas asas oportunitas yang hanya dapat dilakukan oleh Jaksa Agung setelah memperhatikan saran dan pendapat dari badan-badan kekuasaan negara yang mempunyai hubungan dengan masalah tersebut" dalam Penjelasan Pasal 35 huruf c Undang-Undang Nomor 16 Tahun 2004 tentang Kejaksaan Republik Indonesia bertentangan dengan Undang-Undang Negara Republik Indonesia Tahun 1945 secara bersyarat dan tidak mempunyai kekuatan hukum mengikat sepanjang tidak dimaknai Jaksa Agung wajib memperhatikan saran dan pendapat dari badan-badan kekuasaan negara yang mempunyai hubungan dengan masalah tersebut". Pengesampingan perkara demi kepentingan umum berdasarkan Putusan Mahkamah Konstitusi Nomor 29/PUU-XIV/2016, dapat dilakukan setelah kewajiban memperhatikan saran dan pendapat dari badan-badan kekuasaan negara yang mempunyai hubungan dengan masalah tersebut dilaksanakan oleh Jaksa Agung. Saran dan pendapat dari badan-badan kekuasaan negara yang mempunyai hubungan dengan masalah tersebut, wajib diperhatikan oleh Jaksa Agung. Frasa "Jaksa Agung wajib memperhatikan saran dan 
pendapat...” tidak memberikan kewajiban bagi Jaksa Agung untuk mengikuti saran dan pendapat badan-badan yang bersangkutan. Penafsiran Mahkamah Konstitusi bahwa kewajiban Jaksa Agung memperhatikan saran dan pendapat dari badan-badan kekuasaan negara yang mempunyai hubungan dengan masalah tersebut, ditujukan agar ada ketentuan yang jelas dan ketat dalam penggunaan kewenangan mengesampingkan perkara oleh Jaksa Agung.

Pengujian undang-undang terhadap Undang-Undang Dasar, pada dasarnya ditujukan untuk memperoleh keadilan yaitu keadilan substantif. Menurut Mochtar Kusumaatmadja, bahwa suatu sistem hukum positif yang berarti tidak bisa tidak harus berdasarkan keadilan, ketidakadilan akan mengganggu ketertiban yang justru menjadi tatanan hukum itu. Ketertiban yang terganggu berarti bahwa keteraturan dan karenanya kepastian tidak lagi terjamin. ${ }^{29}$ Setiap aturan yang dibuat, di dalamnya terkandung nilai keadilan, karena keadilan merupakan tujuan dari hukum sistem hukum positif. Hukum sebagai perwujudan sistem nilai-nilai mengandung arti, bahwa kehadirannya adalah untuk untuk melindungi dan memajukan nilai-nilai yang dijunjung tinggi oleh masyarakatnya. ${ }^{30}$ Nilai-nilai yang hidup dalam masyarakat, di antaranya nilai keadilan yang dijabarkan dalam bentuk norma (khususnya norma hukum) menjadi pedoman masyarakat dalam menyelesaikan masalah yang timbul dalam kehidupan sehari-hari. Gustav Radbruch mengemukakan mengenai tiga nilai dasar hukum yaitu nilai keadilan, kepastian dan kemanfaatan. Nilai dasar kegunaan menempatkan hukum dalam kaitan dengan konteks sosial yang lebih besar. Dengan demikian, ia merupakan pembuka jalan bagi kajian hukum yang juga memperhatikan interaksi hukum dan masyarakatnya. ${ }^{31}$ Tiga nilai dasar Radbruch merupakan nilai yang berkaitan. Nilai keadilan dapat diperoleh ketika ada kepastian bahwa norma hukum tersebut benar ditaati, sehingga memberikan kegunaan atau

${ }^{29}$ Mochtar Kusumaatmadja \& B. Arief Sidharta, "Pengantar Ilmu Hukum Suatu Pengenalan Pertama Ruang Lingkup berlakunya Ilmu Hukum”, Bandung: Alumni, 2000, hal. 51-52.

${ }^{30}$ Satjipto Rahardjo, Loc. Cit.

${ }^{31}$ Ibid., hal. 15. 
kemanfaatan bagi masyarakat. Permohonan pengujian undang-undang terhadap Undang-Undang Dasar kepada Mahkamah Konstitusi oleh para pemohon merupakan upaya untuk memperoleh keadilan karena merasa haknya telah dilanggar oleh ketentuan Pasal 35 huruf c Undang-Undang Nomor 16 Tahun 2004 tentang Kejaksaan Republik Indonesia beserta Penjelasannya.

\section{PENUTUP}

Pengesampingan perkara demi kepentingan umum sebagai pelaksanaan asas oportunitas dalam penuntutan, memberikan pilihan pada jaksa penuntut umum untuk menuntut perkara tersebut atau mengesampingkannya sehingga tidak dilakukan penuntutan. Pengesampingan perkara demi kepentingan umum sebagai pelaksanaan asas oportunitas merupakan kewenangan Jaksa Agung berdasarkan Pasal 35 huruf c Undang-Undang Nomor Nomor 16 Tahun 2004 tentang Kejaksaan Republik Indonesia, yang hanya dapat dilakukan setelah memperhatikan saran dan pendapat dari badan-badan kekuasaan negara terkait. Pengesampingan perkara demi kepentingan umum pascaputusan Mahkamah Konstitusi Nomor 29/PUU-XIV/2016, bahwa mengesampingkan perkara demi kepentingan umum dapat dilakukan Jaksa Agung setelah kewajiban memperhatikan saran dan pendapat dari badan-badan kekuasaan negara yang mempunyai hubungan dengan masalah tersebut (perkara yang ditangani) dilaksanakan. Saran dan pendapat dari badan-badan kekuasaan negara yang mempunyai hubungan dengan masalah tersebut wajib diperhatikan, agar ada ketentuan yang jelas dan ketat dalam penggunaan kewenangan seponering oleh Jaksa Agung.

\section{DAFTAR PUSTAKA}

\section{Buku}

Andi Hamzah, RM Surachman, Pre-Trial Justice Discretionary Justice dalam KUHAP Berbagai Negara, Jakarta, Sinar Grafika, 2014.

Barda Nawawi Arief, Reformasi Sistem Peradilan (Sistem Penegakan Hukum) di Indonesia, Semarang, Badan Penerbit Universitas Diponegoro, 2012. 
Darmono, Penyampingan Perkara Pidana Seponering dalam Penegakan Hukum, Jakarta, Solusi Publishing, 2013.

Mukti Fajar ND dan Yulianto Achmad, Dualisme Penelitian Hukum Normatif dan Empiris, Yogyakarta, Pustaka Pelajar, 2013.

Kaelan, Filsafat Pancasila Pandangan Hidup Bangsa Indonesia, (Yogyakarta: Paradigma, 2009).

Mochtar Kusumaatmadja \& B. Arief Sidharta, Pengantar Ilmu Hukum Suatu Pengenalan Pertama Ruang Lingkup berlakunya Ilmu Hukum, Bandung, Alumni, 2000.

Satjipto Rahardjo, Sosiologi Hukum Perkembangan Metode dan Pilihan Masalah, Surakarta, Muhammadiyah University Press, 2004.

Jurnal

Damiri Hasan, "Diskresi Seponering dalam Perspektif Hukum Islam:Studi Kasus Pidana Korupsi Bibit Samad Rianto dan Chandra Martha Hamzah", Intizar 22(1), 2016. https://doi.org/10.19109/intizar.v22i1.544

Ferdy Saputra, Syafruddin Kalo, Mahmud Mulyadi, M. Hamdan, "Analisis Yuridis Penerbitan Surat Perintah Penghentian Penuntutan Oleh Kejaksaan Dikaitkan Dengan Azas Oportunitas dan UndangUndang No. 16 Tahun 2004 Tentang Kejaksaan RI", Jurnal Fakultas Hukum, Universitas Sumatra Utara, 2(1), 2014.

Kiki Astuti Wulandary Suti, "Kewenangan Jaksa Agung Dalam Mengesampingkan Perkara Demi Kepentingan Umum”, Kalabbirang Law Journal 2(2), 2020.

Muhamad Iqbal, "Implementasi Efektifitas Asas Oportunitas Di Indonesia Dengan Landasan Kepentingan Umum”, Jurnal Surya Kencana 9(1), 2018. http://dx.doi.org/10.32493/jdmhkdmhk.v9i1.1178

Prianter Jaya Hairi, "Pengesampingan Perkara Pidana Abraham Samad dan Bambang Widjojanto", Info Singkat Hukum 8(4), 2016.

Sri Mulyati Chalil, "Pengesampingan Perkara (Deponering) Oleh Jaksa Agung" Wacana Paramarta: Jurnal Ilmu Hukum, 15(1), 2016.

Tumpal Napitupulu, "Penerapan Azas Oportunitas Berhubungan dengan Tugas dan Wewenang Kejaksaan dalam Sistem Peradilan Pidana (Kajian Perkara Terhadap Terdakwa Novel bin Salim Baswedan)", Jurnal Tanjungpura Law Journal 2(1), 2018. http://dx.doi.org/10.26418/tlj.v2i1.32679

Yeni Handayani, “Jaksa Agung Dan Pengesampingan Perkara Demi Kepentingan Umum”. Jurnal RechtsVinding, 2016.

Peraturan Perundang-Undangan

Putusan MK Nomor 29/PUU-XIV/2016

Majalah

“Kewenangan Seponering Jaksa Agung Diperketat", Majalah Konstitusi, No.120 Februari 2017 


\section{Internet}

Prahassacitta, Vidya, Abolisi: Upaya Pemulihan Status Tersangka Pasca Pemberian Seponering,(http://business-law.binus.ac.id/2016/04/15/abolisi-upayapemulihan-status-tersangka-pasca-pemberian-seponering/ (diakses 29 Agustus 2019).

Rahadian, Lalu, "Jaksa Agung Deponering Kasus Abraham Samad- Bambang Widjojanto", CNN Indonesia | Kamis, 03/03/2016 17:06 WIB, https://www.cnnindonesia.com/nasional/20160303170657-12-115183/jaksaagung-deponering-kasus-abraham-samad-bambang-widjojanto? (diakses 28 Agustus 2019).

"Begini Ahli KUHAP Maknai Seponering 'Demi Kepentingan Umum'”, https://www.hukumonline.com/berita/baca/lt5731c8f006059/begini-ahlikuhap-maknai-iseponering-i-demi-kepentingan-umum (diakses 28 Agustus 2019). 